\title{
Workshop on Drilling of Lake Junin, Peru: Potential for Development of a Continuous Tropical Climate Record
}

\author{
by Donald T. Rodbell, Mark B. Abbott, and the 2011 ICDP Lake Junin Working Group
}

doi:10.2204/iodp.sd.13.10.2011

Lake Junin $\left(11.0^{\circ} \mathrm{S}, 76.2^{\circ} \mathrm{W}\right.$; Fig. 1$)$ is one of the few lakes in the tropical Andes that predates the last glacial maximum. Located at 4000 masl, it covers approximately $300 \mathrm{~km}^{2}$ between the eastern and western cordillera of the central Peruvian Andes. Moraines from alpine glaciers that emanated from the eastern cordillera reach the eastern margin of the lake, but at no time in at least the last several hundred thousand years has the lake been overridden by ice.

Existing sediment cores (20-25 m long) from Lake Junin span $\sim 50 \mathrm{ka}$ and reveal intervals of high glacigenic siliclastic sediment input that alternate with interstadial intervals dominated by the rapid accumulation $\left(\sim 1 \mathrm{~mm} \mathrm{yr}^{-1}\right)$ of authigenic marl (Fig. 2; Hansen et al., 1984; Seltzer et al., 2000). The last deglaciation is marked by a $\sim 6 \%$ increase in the $\delta^{18} \mathrm{O}$ of bulk marl that is nearly identical to the isotopic shift reported

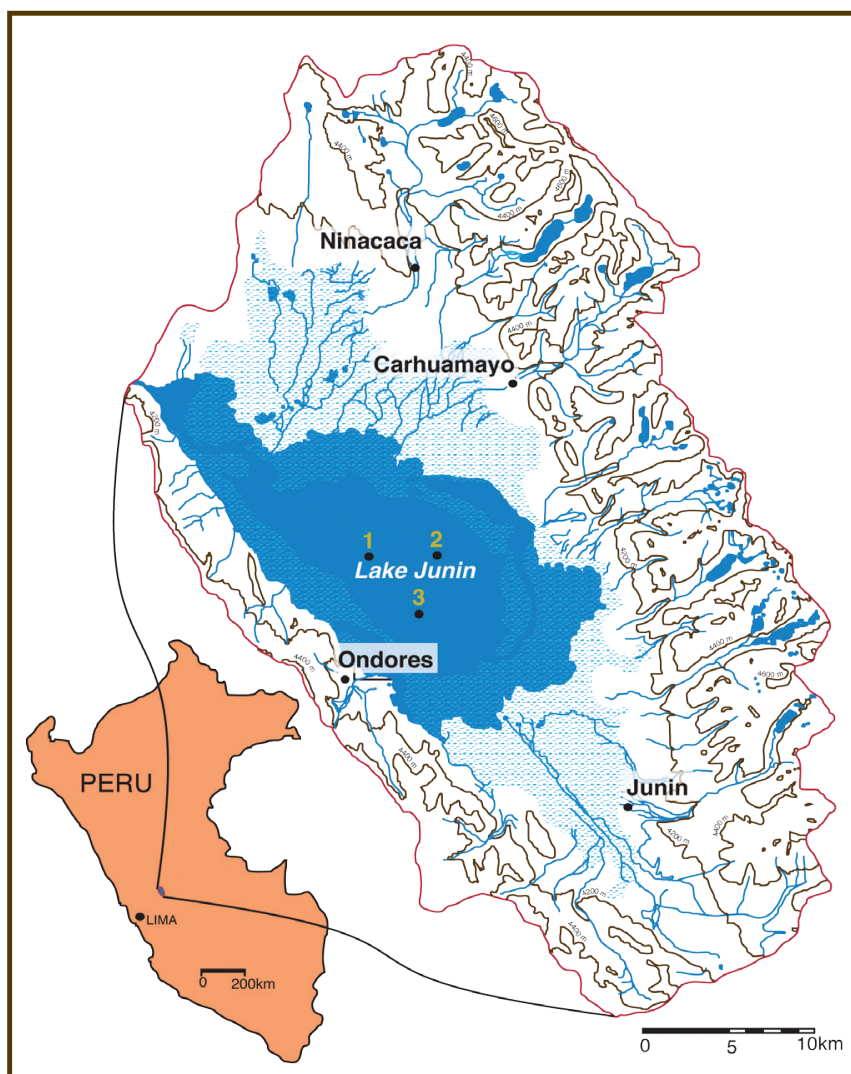

Figure 1. The Lake Junin basin with proposed coring localities 1-3 (Table 1). The eastern cordillera is extensively glaciated, and paleoglaciers reached the eastern edge of the lake on multiple occasions over the past several hundred thousand years. Relatively high rates of glacigenic sedimentation are expected during intervals of expanded ice cover at proposed core sites 1 and 2, whereas site 3 should contain the highest concentration of marl. from the Huascaran ice core (Fig. 3), $\sim 300 \mathrm{~km}$ to the north. Records of $\delta^{18} \mathrm{O}$ from Junin and from other carbonate lakes and speleothems in the region are strongly affected by the hydrological balance of the central Andes, which, in turn, is controlled by the strength of the South American Summer Monsoon (SASM). Controls on the vigor of the SASM include long-term insolation receipts, the mean position of the intertropical convergence zone over the tropical Atlantic Ocean, and the mean state of El Niño Southern Oscillation (ENSO).

Lake Junin contains a sediment record that spans multiple glacial cycles-perhaps covering many hundreds of thousands of years-and the sediments contain high concentrations of authigenic calcite that can be used for both age control through U-Th measurements and production of a subdecadal record of hydrologic variability through stable isotope analyses. However, Lake Junin has never been cored to a depth greater than $25 \mathrm{~m}$. The clear potential of Lake Junin to provide a well-dated high-resolution record of tropical climate evolution spanning several hundred millennia justifies the attention of the scientific community through the International Continental Scientific Drilling Program (ICDP) to ensure the successful acquisition of multiple cores at several locations in the Junin basin (Fig. 1; Table 1).

With this goal in mind, twenty-seven scientists from six countries participated in a workshop in Tarma, Peru on 15-17 June 2011 to discuss scientific priorities and logistical requirements of deep drilling of Lake Junin. Speakers presented overviews of the following topics:

1) the geologic setting of Lake Junin, and the four decades of Quaternary geologic and paleolimnologic research conducted there,

2) the global relevance of a long climate record from Lake Junin,

3) modern climatic controls on stable isotopes in the tropics, and recently-acquired high-resolution $\delta 18 \mathrm{O}$ records from carbonate lakes and speleothems in the Junin region,

4) recently acquired air gun seismic stratigraphy that reveals a total sediment thickness of at least $125 \mathrm{~m}$, no evidence of faulting, and few if any unconformities,

5) the paleoecological potential of Lake Junin sediments,

6) promising new U/Th dates for Junin carbonates, and 
Table 1. Proposed drill sites for Lake Junin.

\begin{tabular}{|c|c|c|c|c|c|c|}
\hline $\begin{array}{c}\text { Coring Site } \\
\text { Number } \\
(\text { Fig. 1) }\end{array}$ & $\begin{array}{c}\text { Latitude } \\
\left({ }^{\circ} \mathbf{S}\right)\end{array}$ & $\begin{array}{c}\text { Longitude } \\
\left({ }^{\circ} \mathbf{W}\right)\end{array}$ & $\begin{array}{c}\text { Water } \\
\text { Depth } \\
(\mathbf{m})\end{array}$ & $\begin{array}{c}\text { Distance to } \\
\text { input streams } \\
\text { of eastern } \\
\text { siliclastic } \\
\text { sediment }\end{array}$ & $\begin{array}{c}\text { Distance to } \\
\text { input streams } \\
\text { of northern } \\
\text { siliclastic } \\
\text { sediment }\end{array}$ & $\begin{array}{c}\text { Distance to } \\
\text { input streams } \\
\text { of western } \\
\text { siliclastic } \\
\text { sediment }\end{array}$ \\
\hline 1 & 11.01 & 76.13 & 11 & distal & intermediate & proximal \\
\hline 2 & 11.02 & 76.07 & 8 & proximal & distal & distal \\
\hline 3 & 11.05 & 76.09 & 8 & distal & distal & proximal \\
\hline
\end{tabular}

*Proximal indicates less than $5 \mathrm{~km}$; intermediate indicates feature is between $5 \mathrm{~km}$ and $10 \mathrm{~km}$, and distal indicates $>10 \mathrm{~km}$.

7) paleomagnetism as a potential dating tool for Junin sediments and as a means of fingerprinting glacigenic sediment in lakes.

One full day was spent circumnavigating Lake Junin by bus with stops to review the regional glacial chronology and to consider possible lake access points and base camps for future drilling and science teams.

Several discussion groups were organized to focus on the themes noted above and were charged with writing short reports to identify the major questions that could be addressed by studying Lake Junin sediments. These groups included 1) stratigraphy and geochronology, 2) organic geochemistry, 3) paleoecology, and 4) regional records of climate.

Lake Junin sits within a fault-bounded subsiding intermontane basin between the eastern and western cordillera of the central Peruvian Andes. Bedrock is dominated by late Paleozoic to Mesozoic carbonates, although glacial erosion of the eastern cordillera has exposed pre-Cambrian crystalline rocks. The lake basin, with a maximum water depth of $\sim 15 \mathrm{~m}$, is dammed at its northern and southern ends by coalescing alluvial fans that emanate from glacial valleys in both cordillera. These fans can be traced to moraines that

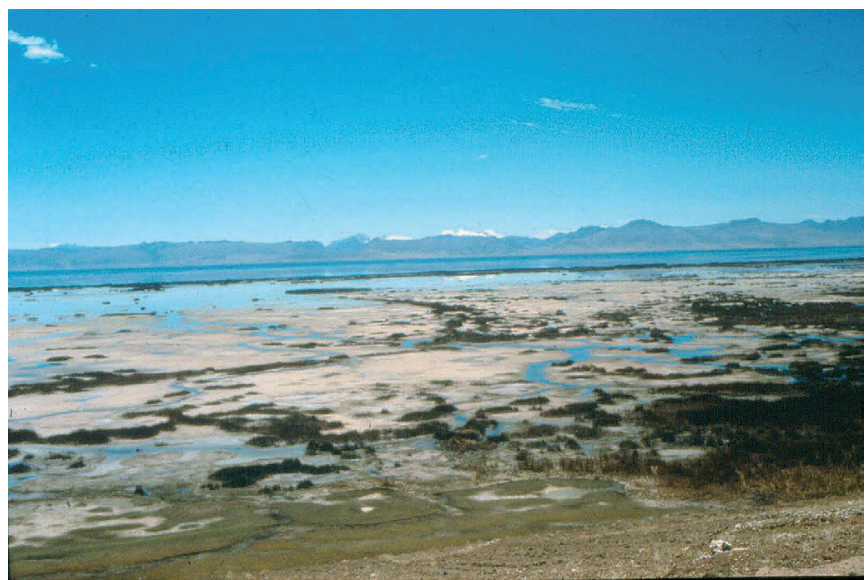

Figure 2. Marl exposed during the dry season along the western edge of Lake Junin; view is looking east across the lake to the eastern cordillera. The marl exposed in this photograph has precipitated on the leaves of rooted macrophytes and has accumulated to form a bioherm several meters thick. The glacier-clad summits in the distance fed valley glaciers that reached the eastern edge of Lake Junin on several occasions in the last million years (Smith et al., 2005a, 2005b). are more than $250 \mathrm{ka}$, and thus the lake is at least this old. Detailed moraine mapping coupled with nearly 200 cosmogenic radionuclide $\left(\mathrm{CRN} ;{ }^{10} \mathrm{Be},{ }^{26} \mathrm{Al}\right)$ exposure ages from boulders on the crests of moraines clearly indicates that during the maximum extent of late Cenozoic glaciation on the Junin Plain, paleoglaciers reached the lake edge, but at no time in perhaps as much as one million years or more has Lake Junin been overridden by ice (Smith et al., 2005a, 2005b)

Reconnaissance seismic-reflection surveys suggest that the Lake Junin basin contains a thick sedimentary sequence amenable to sampling by drill core. High-resolution chirp $(4-24 \mathrm{kHz})$ data collected in 2008, combined with existing core data, reveal tens of meters of interbedded marl and lacustrine mud, the latter dominated by glacial flour. In shallow water $(<6 \mathrm{~m})$, these sediments are incised by chan-

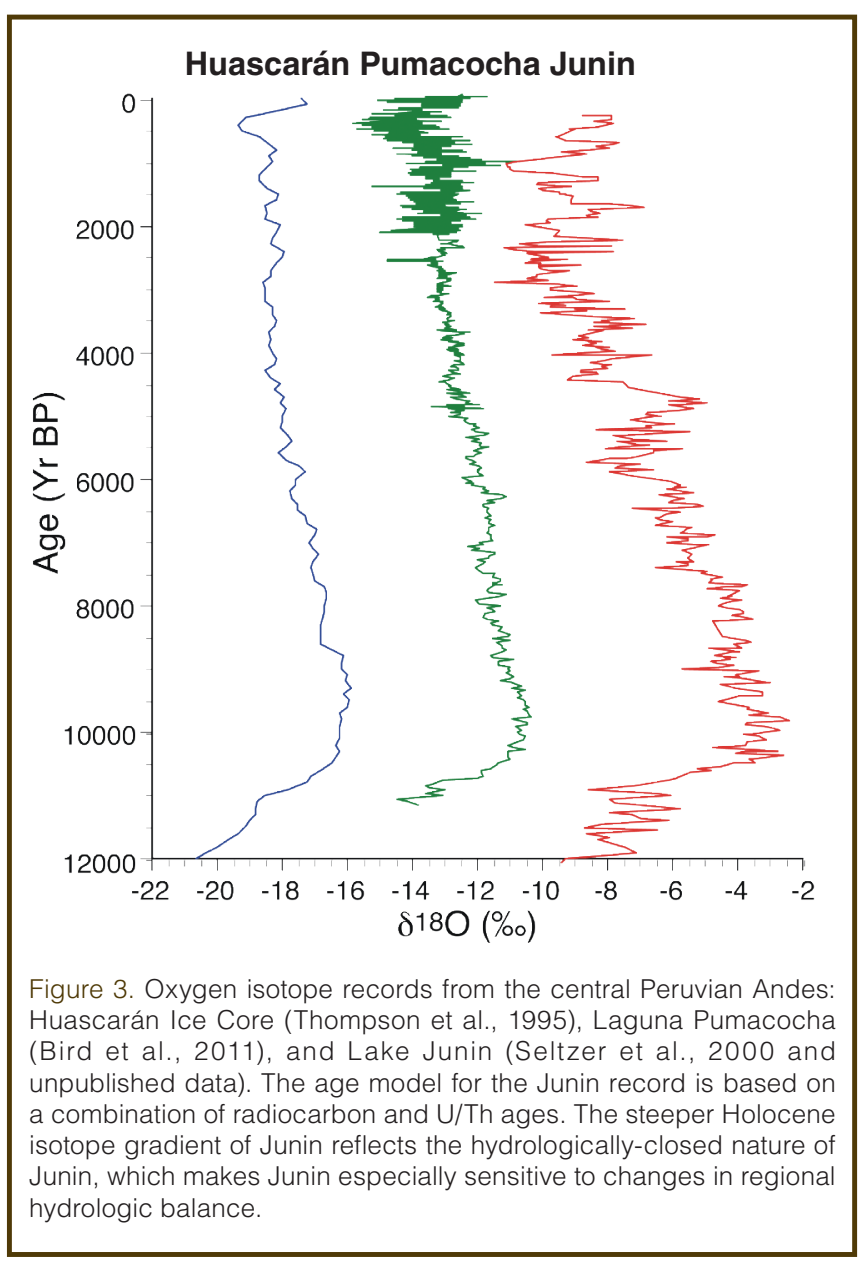


nels related to a Holocene lowstand of the lake. An air gun seismic survey in 2011 successfully imaged as much as $150 \mathrm{~m}$ of nearly horizontal sediment with no evidence of deformation. Details of the stratigraphy were obscured by ringing in the shallow water column, but several prominent, continuous reflections were observed that could be traced across the lake basin. One of these, reaching a maximum depth of about $125 \mathrm{~m}$ below the lake floor, was especially prominent, but several additional deeper reflections were observed below it. The prominent deep reflection could be mapped throughout the survey area, and it is flatter than the modern lake floor. These relationships suggest broad-scale basin subsidence and a lack of local deformation. They also suggest that at the time that the deep reflector was formed, the lake was somewhat larger than at present. No evidence has been observed in the central part of the lake for large-scale lake-level fluctuations, such as wave-cut shorelines, fluvial channels, or low-stand deltas. No local tectonic deformation was observed, and no widespread gas, either volcanic or biogenic, was observed in the sedimentary sequence.

U/Th dating will be an essential element in developing age models for longer cores from Lake Junin. Preliminary analyses of radiocarbon-dated Holocene sediments from the lake indicate that these interglacial sediments are nearly ideal for U/Th measurements, with high carbonate percentages ( 90\%), very high ${ }^{234} \mathrm{U} /{ }^{238} \mathrm{U}$ ratios, and low contamination by detrital ${ }^{230} \mathrm{Th}$. Though errors on dates are small compared to other lacustrine sediments, errors on Holocene dates are still on the order of $1000 \mathrm{yr}$ and are dominated by uncertainty in the detrital ${ }^{230} \mathrm{Th} /{ }^{232} \mathrm{Th}$ ratio used to correct for detrital ${ }^{230} \mathrm{Th}$. Uncertainty in this ratio is currently estimated at $\pm 100 \%$. Future work will seek to reduce these errors by 1 ) better characterizing ${ }^{230} \mathrm{Th} /{ }^{232} \mathrm{Th}$ ratios in the detrital material through analysis of zero-age samples and use of isochrones, and 2) careful selection of small (a few milligrams), extremely clean samples. In previous interglacials, relative errors will be substantially smaller due to decay of the initial detrital ${ }^{23} 0 \mathrm{Th}$; even assuming that uncertainty in the detrital ${ }^{230} \mathrm{Th} /{ }^{232} \mathrm{Th}$ is not reduced, errors in samples from $125 \mathrm{ka}$ should be $<1 \mathrm{kyr}$, assuming the sediments are similar in composition to Holocene sediments.

Lake Junin offers an excellent venue to test current hypotheses of paleoecological responses to climatic change. Abrupt and non-linear responses to change are among the most important issues to be investigated. The transitions of biota ranging from plants to ostracods into and out of previous interglacials, and responses to millennial-scale events will allow us to test a wide range of theories relating to community composition, ecosystem resilience, migratory response, and even extinction.

Workshop participants agreed that the regional-global scale rationale for a concerted effort through the ICDP to acquire multiple long cores from Lake Junin includes the following points. 1) Lake Junin is in a critical location with respect to long-term ENSO-Southern Hemisphere monsoon dynamics. 2) The potential of coupling a marl isotope record from Junin with the emerging nearby $\delta^{18} \mathrm{O}$ record from speleothems to produce a paleohumidity record would be a unique contribution to the paleoclimatology and paleoecology of South America. 3) Lake Junin may provide a unique isotopic and paleoecological record of Dansgaard-Oeschger (D-O) and Heinrich events linked to conditions in the core of the SASM region of the Amazon Basin. 4) The glacigenic sediment record from Lake Junin will provide the first continuous record of glaciation and glacial erosion spanning several hundred millennia in tropical South America.

\section{References}

Bird, B, W., Abbott, M. B., Rodbell, D. T., and Vuille, M., 2011, Holocene tropical South American hydroclimate revealed from a decadally resolved lake sediment $\delta^{18} \mathrm{O}$ record: Earth and Planetary Science Letters 310, 192-202.

Hansen, B.C.S., Wright, H.E., Jr., and Bradbury, J.P., 1984. Pollen studies in the Junín area, central Peruvian Andes. GA Bull., 95:1454-1465, doi:10.1130/0016-7606(1984)95\%3C1454:PSI TJA\%3E2.0.CO;2.

Seltzer, G., Rodbell, D., and Burns, S., 2000. Isotopic evidence for late Quaternary climatic change in tropical South America. Geology, 28:35-38, doi:10.1130/0091-7613(2000)28\%3C35:I EFLQC\%3E2.0.CO;2.

Smith, J.A., Finkel, R.C., Farber, D.L., Rodbell, D.T., and Seltzer, G.O., 2005a. Moraine preservation and boulder erosion in the tropical Andes: Interpreting old surface exposure ages in glaciated valleys. J. Quat. Sci., 20:735-758, doi:10.1002/ jqs. 981 .

Smith, J.A., Seltzer, G.O., Farber, D.L., Rodbell, D.T., and Finkel, R.C., 2005b. Early local last glacial maximum in the tropical Andes. Science, 308:678-677, doi:10.1126/science.1107075.

Thompson, L.G., Mosley-Thompson, E., Davis, M. E., Lin, P. -N, Henderson, K. A., Cole-Dai, J., Bolzan, J. F., and Liu, K. -b., 1995. Late glacial stage and Holocene tropical ice core records from Huascarán, Peru. Science 269, 46-50.

\section{Authors}

Donald T. Rodbell, Union College, Schenectady, NY 12308, U.S.A., e-mail: rodbelld@union.edu.

Mark B. Abbott, Department of Geology and Planetary Science, University of Pittsburgh, 4107 O'Hara Street, Room 200, SRCC Building, Pittsburgh, PA 15260-3332, U.S.A., e-mail: mabbott1@pitt.edu.

and the 2011 ICDP Lake Junin Working Group

\section{Photo Credit}

Fig. 2: Donald T. Rodbell, Union College 